\title{
Geography and Indigeneity III: Co-articulation of colonialism and capitalism in indigeneity's economies
}

\author{
Sarah A Radcliffe ${ }^{1}$ \\ University of Cambridge, UK
}

\begin{abstract}
In this final report of three, I examine Indigenous peoples' dynamic co-constitution with contemporary political economy in its manifestations of neoliberalism, resource extractivism, reordering production and labour relations. Indigenous subjects and spaces are not reducible to the status of capitalism's side-effects, necessitating analytical attention to the coarticulation of colonialism and capitalism in particular, variegated ways. Debates around extractivism, neoliberalism and economic want are hence recent manifestations of five hundred year old disputes over monetary and normative values, resources and livelihoods. Whether as corporations, labourers, welfare recipients, or ambassadors for culturally distinctive forms of livelihoods-exchange, Indigenous peoples occupy complex, relational positions across economic spheres. The paradox of indigeneity's economies is that indigenous populations have been constituted as Other to homo oeconomicus yet their embeddedness within the economic flows, labour processes and forms of accumulation that make the modern world belie any separation. The report ends by raising questions about decolonising accounts of indigneity's economies.
\end{abstract}

\section{Keywords}

embeddedness, indigeneity's economies, investible, neotribal capitalism, variegated neoliberalism

\section{Introduction}

The reverse action of the takis-thakis ${ }^{2}$ alters the rhythm of the neocolonial capitalist machine, creates intermediary spaces, and re-appropriates the methods and practices of the global market, just as it affirms its autochthonous circuits, its repertoire of special knowledges, and the advantages and artifices that allow these communities and enterprises to self-confidently face this unequal scenario and its many forms of violence. (Rivera Cusicanqui, 2014: n.p.; my translation)

1 Corresponding author: Sarah A. Radcliffe, Department of Geography, University of Cambridge, Cambridge CB2 3EN, UK. Email: sar23@cam.ac.uk

2 Thaki, according to Silvia Rivera, is "a polysemic Aymara word that connotes the itineraries of ritual libations, dances and chants in the routes that connect .... centres of power in successive historical horizons of signification and routinization" (Rivera Cusicanqui, 2014: n.p., my translation). She amplifies its meanings to discuss a sonorous territoriality (takisthakis) that displaces itself through space-time and generates heterogeneous spaces of Indigenous and non-Indigenous actors, economies and practices across an intermediate arena of antagonism and seduction. 
[Indigeneity is] intertwined with property struggles, as [well as] dynamically constituted and reconstituted in relation to the prevailing political economy. (McCormack 2012: 430)

Indigenous peoples occupy multiple, complex, relational positionings across diverse economic, social, political, institutional, meaningful and epistemic spheres, which are expressed in material, embodied, grounded and inter-subjective ways. Extending previous reports on geography and indigeneity (Radcliffe, 2017, 2018), the focus here is on Indigenous peoples' dynamic co-articulation with contemporary political economy in its manifestations of neoliberalism, resource extractivism, and the reordering of production and labour relations. Current research helps to deepen our understanding of capitalist economic relations in Indigenous inhabited lands (urban and rural) and by Indigenous actors. Yet 'the particulars of [capitalism's and colonialism's] co-articulation with local formations of indigeneity' (Pasternak, 2014: 180; Bryan, 2017) are not always systematically interrogated. In this context, critical postcolonial and decolonial perspectives offer a means to re-situate economic analysis in relation to dispossession and ongoing colonization, which define the terrain that Indigenous peoples engage with and live within, under the logics of colonial modern economic processes, values and distributions. Whether in settler colonial countries in the wealthy minority world or impoverished global Souths, decolonizing accounts foreground the urgency of material survival of Indigenous groups alongside the multiple ways of knowing and being in colonial modernity and its economies (De Leeuw and Hunt, 2018; Rivera Cusicanqui, 2014). ${ }^{3}$ Indigenous economic spaces and subjects are not reducible to capitalism's side-effects, ${ }^{4}$ nor are Indigenous peoples uniquely subordinated to re-colonizing capitalisms. Building from the phenomenological parity between indigeneity, colonialism, capitalism offers an analytical framework that challenges essentialism by being grounded in strongly situated and ethnographic accounts. The plural co-articulations between (dynamic and geographically differentiated) Indigenous peoples, capitalism, and colonial modernity can be understood as what I call indigeneity's economies.

The sheer diversity and complexity of indigenous relations with economic transactions, flows and resources -- let alone labour relations -- are highlighted by recent events. In New Zealand, Māori groups are moving into sustainable energy production to respond to climate change. In Peru, a radio journalist works unpaid for years to creatively build a unique vocabulary in the Quechua language and then provides live commentary on the 2018 World Cup matches (Vilchis 2018). Further north, incarcerated Indigenous women are put to work in Mexican gaols (Aida Hernandez 2018, pers. Comm.). Also in Mexico, an Indigenous

3 Decolonial and postcolonial frameworks are more widespread in discussions of coloniality and subjectivity (covered in my previous progress reports) than in relation to economy (see notable exceptions below).

$4 \quad$ These are not comparable due to (proclaimed/claimed) ontological difference, the nature of inter-subjective/ more-than-human relationality, and the ways that capitalism mobilized notions of race. 
social enterprise won court backing to provide a low cost mobile phone service in Indigenous-majority states. These examples illustrate the paradoxical geographies of Indigenous peoples in early 21 st century political economies. On the one hand, indigenous corporations can leverage investment capital, while elsewhere indigenous labouring bodies continue to be treated as unworthy of fair payment. Throughout this period too, international rights instruments have failed to secure resources and livelihoods for most of the world's Indigenous peoples.

In this final progress report, I examine what is happening, how we analyse it, and what the implications are for Indigenous geographies. Section II outlines the tensions attendant in conceptualizing and critically analyzing Indigenous peoples and economic relations. Section III focuses on the parameters of Indigenous peoples' agency within capitalism, especially in relation to variegated neoliberalization. Following this, Section IV outlines how Indigenous peoples and places engage selectively with financial flows (capital investment, 'green' finance, wages, and welfare payments), which leads onto a discussion of the concept of neotribal capitalism (section V). Before turning to conclusions, the penultimate section VI explores the ways law channels the kinds of economic relations that are forged between and across Indigenous-non-Indigenous actors and institutions.

\section{Conceptualizing relations between Indigenous peoples, economy and indigeneity}

Indigeneity's constitution through relations of power and difference at multiple scales includes economic relations of capitalism. It's a measure of the uncritical nature of mainstream conceptions of indigeneity that this point has not, until recently, been explored with respect to capitalism and specifically, neoliberalism, although Indigenous peoples have long raised the distinctions between stereotype and harsh reality. Frequently, notions of indigeneity (as powerful representations and positionings produced by dominant actors) represent Indigenous peoples as if they were somehow outside the mainstream ('modern') economy, and guided by moral economy and kinship in primarily non-monetary exchange and familial labour (compare Allegretti, 2018). Other beguiling simplifications occur in mainstream institutions such as the World Bank and European Union. Although they quantify the dire economic situation of indigenous peoples across the world, international financial institution policies turn to poverty alleviation, cultural recognition, and corporate social responsibility schemes to mediate Indigenous-capitalism's frictions (eg. O'Faircheallaigh and Ali, 2008). Structural influences on the economy and their pernicious effects on Indigenous populations are systematically ignored or only partially recognized, as in post-Millennium Development Goals policy (Enns et al., 2015).

Social science has grappled for a long time to make indigeneity's complex enmeshment with political economy visible (see Howard-Wagner et al., 2018a). Critical voices highlight how Indigenous peoples in practice and politics challenge naive and romantic representations, and draw attention to global-local implications of capitalism's expansion and rapacious resource (and labour) exploitation in Indigenous lands and territories (eg. Rata, 2000; Stewart- 
Harawira, 2005). Indigenous and critical scholars increasingly examine neoliberal practices as a form of colonialism, emphasizing the structural dimensions to Indigenous exclusion (Howard-Wagner et al., 2018b: 1). Yet at least two divergent strands can be discerned within these critical perspectives. In one strand, Indigenous anti-capitalist resistance is analysed within a diverse economies and non-capitalist futures framework (Gibson-Graham 2006; also Bargh, 2018; Wilson et al, 2018). ${ }^{5}$ Gibson-Graham's work on postcapitalist political economies additionally raises the possibility of stimulating exchanges between economic geographies and Indigenous geographies. These disciplinary subfields share interests in sitespecific configurations of embedded socio-economic dynamics, the multiscalar operation of economic flows and transactions, and moving beyond reified and stereotyped analysis of subjects and processes. For this reason, the progress report hopes to engage economic geographers to consider indigeneity's economies, as well as speak to geographers already interested in indigeneity.

Alongside the diverse economies literature exists work inflected by Foucault and Marxism that pays greater attention to complex, locally specific articulations of capitalist processes and how they allocate Indigenous peoples into widely divergent economic relations. This work seeks to document Indigenous peoples' complex and differentiated relations with capitalism, whether as passionate advocates for entrepreneurialism and corporations, through to life-long embeddedness in capitalist labour markets, to variable (and variably successful) endeavours to make economic practices more solidary. These two interpretive frameworks occupy a tensioned geopolitics of knowledge production, in which researchers and writers (including Indigenous scholars) make crucial decisions about method, theory, political stance, and collaborative dynamics with informants that each have profound implications for how Indigenous peoples are represented and contribute to our knowledge of Indigeneity and economy (De Leeuw and Hunt, 2018). In this context, attention to the grounded processes and interactions at multiple scales that place Indigenous peoples in the 'protected' remit of corporate social responsibility (CSR), environmental, or poverty-alleviation programmes while simultaneously re-colonizing their lands and resources becomes an urgent endeavour (see Li, 2014). The differentiated articulations of Indigenous subjects with economic relations of employment, investment, property, resource extraction, and with the wider infrastructures of law, policy and construction of value bring complex economic relations into focus. Beyond the production side of indigeneity's entanglements with economic relations, Indigenous peoples are also distinctively constituted through welfare and poverty.

These analytical tensions are illustrated in reviews of anthropologist Alex Golub's masterful work Leviathans at the Gold Mine (2014), which provides a rich ethnography of 50 years' interaction between a mining corporation and a heterogeneous Indigenous population. Some reviews read his text as illustration of the gold-mining company trampling Ipili Indigenous livelihoods. Others discern in Golub's ethnography a suggestion that the grassroots can exert

$5 \quad$ At times these accounts convey essentializing (occasionally strategically essentializing) representations of Indigenous peoples as intrinsically anti-capitalist, characterised by distinctive ethics and epistemologies. 
some agency in shifting away from subsistence Indigenous economies. Yet other reviews highlight how Ipili social identity emerges between cosmology and bureaucracy into multifaceted social and economic ties that are maintained with and beyond the mining corporation. Golub himself starts with the proliferation of actors, tracking how kinship and corporate power differentiate and position individuals in multiple, overlapping affiliations (Golub 2014: 3-4, 133), thereby seeking to ground-truth and contextualise agency instead of seeing it as uniquely a quality of Indigenous peoples or of capitalism.

Analysing the differentiated positionality of Indigenous peoples' across plural economic spheres and relations is all the richer for starting from the processes by which colonial modernity places Indigenous peoples at the heart of struggles over value within dynamic economic processes.

\section{Indigeneity, economy and agency}

The question of Indigenous agency hence becomes a central concern. Indigenous populations and groups have undergone major transformations in how they interact with, engage and make decisions in capitalist economies around the world. Yet research also concludes that capitalism - in its multifarious forms, many of them neoliberal -- represents a highly ambivalent and dangerous space within which indigenous subjects can pursue security, meaning, and autonomy, leaving no guarantees. In other words, economic relations structured as they are through colonial modern distributions, epistemologies and power -offer highly ambivalent spaces for the expression of -- and systematic gains from -indigenous agency. Structural disadvantages, including racialized and discriminatory labour and financial markets, dispossession by larger economic entities, and property relations skewed against indigenous 'anomalies', all work to circumscribe the scope and type of economic relations for Indigenous groups and individuals. In many cases, Indigenous groups make livelihoods despite and in the interstices of the globally-endorsed activities that get counted in GDP and promoted by international financial institutions.

Yet the trend in some countries is for indigenous settlements to become not-for-profit companies, corporations, or investment vehicles, as detailed below. Such transformations and variegation raise crucial challenges for how we can conceptualize, analyse and theorise the relationship between indigeneity and economy. If, as I argued in previous reports, indigeneity comprises a situated set of knowledges and relational constitutions of subjects and spaces, economic relations are also a component in how indigeneity is constituted. However rather than positing an agency-less indigenous subject confronting a depersonalised but all-powerful capitalism, the question is what frameworks can be applied to capture nuances of structure and agency while acknowledging indigeneity's distinctive excess to western economic theory?

Recent literature suggests that such questions are best addressed through detailed explorations in context. In Bolivia, urban Indigenous women are traders, sellers and 
consumers for used clothes in the informal sector, finding themselves in stratified and segmented labour markets and market sites even as they hustle and earn for greater profit (Maclean, 2014). In the Bolivian lowlands, Anthias (2018) traces the reasons for Guaraní peoples' pragmatic negotiations with gas extraction companies, negotiations and analysis that take into account Guaraní more-than-economic struggles for citizenship and frustrated projects for territorial autonomy (blocked by regional elite landowners). Responding to indigenous assertions of jurisdiction in Canada, capitalist actors introduce new means to evaluate the perceived risks to corporate and state infrastructure and capital flows (Pasternak and Dafnos, 2017). The case highlights how risk mitigation reproduces certain dynamics of indigenous dispossession, even as first nations enact sovereignty over resources (also Stanley, 2016). Together, these diverse accounts highlight Indigenous economic activity within and beyond historic territories, and agency expressed through multitudinous practices and scales.

Under prevailing neoliberal capitalism, Indigenous subjects are necessarily entrained within the often ambiguous, pervasive and continuously mutating configurations of neoliberal subjectivity, discipline and agency which can encompass protections for Indigenous peoples even as it promotes the free market as a route to equal status with non-indigenous actors. The elusive promise of autonomy is promoted to indigenous groups and, in certain circumstances, provides Indigenous subjects with visions of greater political economic leverage: 'Acknowledgement [by the United Nations and transnational institutions] of the impact of colonialism becomes about the elimination of impediments to the right to economic development' (Howard-Wagner, et al., 2018b: 11).

From neoliberal New Zealand to neoliberal Chile, Indigenous individuals and groups are finding in entrepreneurialism a potent promise of economic independence from the postcolonial state, and a means to counter racist stereotypes, with the potential to provide the financial basis for greater autonomy and self-determination (see among others LaDuke, 2009; Brabazon, 2017; Di Giminiani, 2018). Indigenous groups establish business councils to forge direct connections with potential investors, including the Chinese, as part of a politics of selfaffirmation in which oversight of economic activities is understood as a form of sovereignty (Montsion, 2015). Just as rearticulated markets create spaces for Indigenous peoples, so too new and old forms of exclusion are reworked. Corporate social responsibility programmes recast old stereotypes in new settings as a way to discredit Indigenous actors who challenge mining corporations (see Horowitz, 2018 on the Pacific).

This section suggests that Indigenous agency in economic relations is not universal, but deeply geographical; the variegated nature of neoliberalism itself interacts with the plural historical and contemporary spaces of Indigenous access to resources, livelihoods and security (see Tassi, 2016). Analysis then is less about tracking the replacement of indigeneity by a neoliberal subject with a veneer of authenticity, and more about identifying in situ the complex dance of curtailed agency and neoliberal imaginations over a terrain of sharply skewed distributions of material resources and epistemological validity. That said, more work is needed on the differential agency of heterogeneous Indigenous subjects, taking into account hierarchical relations within and across Indigenous groups (Radcliffe, 2018). 


\section{Indigenous lands and resources become investible}

Since the mid-1990s Indigenous subjects have been encouraged to develop the market potential of ethnic difference, a policy formula that has evolved new iterations and emphases in the early twenty-first century (compare Radcliffe \& Laurie, 2006). Another pattern, documented primarily in Anglophone settler societies, is for the creation of Indigenous corporations and economic instruments based on Indigenous lands. Less visible in these debates are the labour relations experienced by Indigenous subjects, within and outside historic territories, and the dynamics between tax, welfare and Indigenous peoples, themes I address in turn.

Indigeneity - that is, dominant representations of the quality that makes Indigenous peoples distinctive - still has global economic traction. Social enterprises are increasingly associating themselves with Indigenous people as active stakeholders in enterprise and self-organisation (Chandra, 2018). Ethnographic research unpacks and explains these broad findings. Indigenous leaders and subjects perceive entrepreneurial activity as a means to confront racialized stereotypes about their capacities in commerce and productive work. Yet engagements with neoliberal tropes of business acumen and opportunity are set around with astute scepticism and wariness. In Chile, Mapuche leaders view entrepreneurialism with considerable ambivalence and remain sceptical of the state's "governance of hope" that directs them into free market activities (Di Giminiani, 2018). Indigenous actors too continue to pursue the legal-cartographic strategy of trying to secure control over resources, despite the strategy's often ambivalent outcomes (Rye \& Kurniawan, 2017). In Peru, government promotion of digital technologies for productive innovation creates new rural-urban networks between rural artisans and IT professionals, even as wages are driven down by 'national' export policy (Chan 2013).

Neoliberal promotion of Indigenous products and services in global markets reflects one dimension of a colonial modern attribution of continuity and (non-state) stability to Indigenous peoples and places. Social enterprises exploit this association, while a more recently documented process to treat territories as collateral and as quasi-stocks and shares takes this expansion of capitalism in significant new directions, because the qualities of embodying historic-continuity-at-one-remove are found not only in niche markets, but increasingly as investment opportunities in a crisis-prone world. In some parts of the world, Indigenous life-worlds and territories acquire capitalist values as a means to achieve investment stability in the context of volatile capitalism. ${ }^{6}$ In Canada, shareholders were encouraged to invest in agricultural land held by Indigenous communities, land whose racial overtones stabilized investment processes and boosted revenues for the non-Indigenous

\footnotetext{
Polanyian logics of separating Indigenous peoples from capitalism are found elsewhere (Anthias and Radcliffe, 2015).
} 
investment firm (Sommerville 2018). In New Zealand, McCormack (2012: 430) argues that indigenous resources are increasingly viewed as stocks and shares, while land becomes investment capital. From the perspective of potential investors - which include settler colonial states, China and transnational companies, among others -- Indigenous territories represent a business opportunity. A business case is made and justifies new economic relations (Pasternak 2014), whether to gain access to minerals or agricultural land, or to benefit from steadily rising land values. Alongside NGO and World Bank land titling, the securitization of property titles occurs in dialectical relation with global market interest in hydrocarbons and emission reduction (RRI, 2016). For critical scholars, these processes re-colonise Indigenous actors and lands, as they are decided by risk calculations and stock markets in New York and London rather than through Indigenous governance.

'New' economic sectors are also becoming entangled with Indigenous insertion into labour, energy and product creation and circulation, highlighting again the diverse positioning and contingent nature of indigeneity's economies. Global demand for ethical consumerism alerts companies to the importance of certification, in turn entailing highly ambiguous relations with Indigenous populations and territories. In Chile, the FSC (Forest Stewardship Council) recruits companies to its social and environmental standards although Indigenous leaders view these as fig leaves for destructive capitalism and the maintenance of internal colonialism (Hale and Millaman Reinao, 2018). Elsewhere, diverse Indigenous communities are active in producing or resisting sustainable energy. In Aotearoa New Zealand, Māori ethics inform a growing number of companies, in a context where populist arguments for protectionism and local control are widely supported and hopes for sustainable community economies are high (Bargh, et al., 2014; MacArthur and Matthewman, 2018). By contrast, Avila (2018) finds that one strand of resistance to wind farms worldwide emerges in defence of indigenous territories, local livelihoods and communal development projects (mirroring Indigenous rejection of REDD+ schemes). Located largely in areas bypassed by development, Indigenous groups act against the 'green' economy and its perceived appropriation of resources and territory. In another part of new economies, Indigenous control over intellectual property of music and performance is fraught with disputes with the state, legal frameworks and widespread misconceptions about exchange and value in Indigenous societies (Bigenho and Stobart, 2016). A broader point arising from this work is how specific colonial legacies shape Indigenous relations with, and reactions to, new economic relations.

Labour relations of Indigenous and non-Indigenous actors comprise a minor strand in recent research, yet importantly demonstrates how parallel -- at times overlapping -- processes intertwine and shape livelihoods and diverse economies. In Indigenous territories, time and effort are not always entirely monetized, meaning that voluntary work and other forms of labour continue to get things done both in low-income and wealthy countries (Bargh, 2018). Because of historic state underinvestment in education and infrastructure in Indigenous areas, Indigenous subjects are often unable to credentialize themselves to gain employment in new ventures (Howlett et al., 2011: 319). Detailed research illustrates how various ethnic groups living in a single region are entangled in different employment sectors from agriculture 
through to oil extraction and road building (Bozigar et al., 2016). With the rise of Indigenous autonomous governments and neotribal corporations (see below), new forms of employment expand, in some cases boosted by settler colonial state training and employment programmes that include Indigenous peoples. Additionally, public-private partnerships entail Indigenous groups in bidding to provide services to their own communities (Howard-Wagner et al, 2018a).

Yet few studies pay attention to the dynamics of class and employment status within Indigenous groups (see Li, 2014 for a rare exception). In the United States, Rose's examination of anti-unionism in Indian reservations is a useful reminder of how inequalities pervade Indigenous populations (Rose, 2015; compare Borowiak et al., 2018 on racialized exclusion in the solidarity economy). In Ethiopia, Korf and co-authors (2015) document how only a small number of Indigenous actors are able to invest capital and create profits under processes of state land appropriation. Extracting rent from previously communal resources, these local merchants are 'not the usual suspects of the land-grab literature: not foreign and corporate, but "indigenous" and pastoral' (Korf et al., 2015: 897; compare Grydehøj and Ou, 2017). These few studies examine Indigenous labour relations within Indigenous (historic) territories, rather than trace labour dynamics among 'de-territorialized' subjects, leaving a gap in our understanding of urban multiethnic economies and Indigenous experiences in intersectional and segregated labour markets.

A third strand in the literature provides a preliminary glimpse into Indigenous peoples' position as tax-payers and welfare recipients. Relations of tax and welfare are, on the evidence presented, constituted through colonial-modern power. With respect to taxation, Indigenous populations frequently had a distinctive tax status that originated in colonial governance. However that situation is rapidly changing, with diversifying indigenous economic activities and states' fiscal imperatives to stabilize public finances (eg. Sheild Johansson 2018). As in the case of economic relations described above, taxation reveals the frictions between Indigenous self-representation and politics, and hegemonic representations of indigeneity. Bedouin settlements perceive themselves as taxpayers and property owners under official and customary laws and, on this basis, legitimate interlocutors in negotiations over land (Kedar et al., 2018). Yet Israeli land law originates with Ottoman and British statutes that treat Bedouin as nomadic invaders and thereby delegitimize Bedouin presence. With respect to welfare, colonial modern dispossession of Indigenous groups has rendered them the target for welfare programmes. In Australia, Bielefeld (2018) analyses how costcutting measures in welfare administration were combined with disciplining surveillance of 'problematic' Aboriginal practices, exacerbating the lack of employment in remote areas, and postcolonial geographies of unevenly funded services that result in structural economic disadvantage and the reproduction of racism.

Across the spheres of branding, investible stocks, divisions of labour, and financial relations of tax and welfare, the sheer diversity of Indigenous relations with and through capitalism and economy is evident. Indigenous agency is highly constrained by the broader hegemonic dynamics of capital flows that create uneven development. However colonial difference is 
also present and shapes the legislative, commercial and production frameworks within which Indigenous peoples operate. The co-articulation of dynamic economic processes with stubbornly durable representations and framing of indigeneity generate geographically specific, embedded, economic relations for Indigenous peoples and their (varying) resources of labour, territory and ethnic distinctiveness.

\section{Neotribal capitalism and Indigenous corporate actors}

With a marxist analytics, some writers examine the origins, dynamics and consequences of Indigenous groups' wholesale embrace of capitalist corporations in pursuit of control over economic activities in their territories. Engaging centrally with the issues of agency and structure summarized above, these discussions primarily focus on the Anglophone settler colonial states of New Zealand, the United States, Canada and Australia. In summary, the work argues that a specific form of capitalism exists in Indigenous reservations and territories, which upholds an ideology of tradition even as it exploits labour and resources. In this formulation, neotribal capitalism comprises the 'articulation of exploitative class social relations of production and a neotraditionalist ideology of revived communal relations within a social formation structured by a capitalist regime of accumulation' (Rata, 2000: 33; also Rata, 1999). In work on New Zealand, Elizabeth Rata concluded that an Indigenous core of life and relations have been compromised by the capitalist economy, which subverts local ideologies and results in a distinctive, separate, regime within capitalism (Rata, 2000). Updating the work a decade later suggests that a neotraditionalist ideology conceals and depoliticizes class relations, thereby insulating neotribes from criticism and promoting capital accumulation (Rata, 2011).

Since these provocative contributions, geographers and others have examined the ways in which Indigenous groups become corporate actors and the consequences for politics and identity. Working in the United States, Rose (2015) extends Rata's approach by examining how neotribal depoliticization of labour exploitation renders capitalism more 'acceptable (if not preferred) when it is Indigenous people exploiting the land and each other, or ... providing the legal acquiescence for exploitation for outside firms' (Rose, 2015: 232). In a Canadian case that engages with neotribal capitalism arguments, Bennett (2018) argues that Indigenous-owned companies fulfilled a longstanding desire to build an Arctic road to promote development, demonstrating indigenous agency tempered by minimal expectations.

Indigenous theories of settler colonialism and capitalism, to varying degrees influenced by Marxism, provide a different entry point to discuss indigeneity's economies. In these accounts, neoliberal promises of freedom are analysed in relation to Indigenous peoples' structural colonial disadvantage in state processes. Canadian state bureaucracies for example re-designated Indigenous territory as a form of municipal property, inspired by neoliberal advocates de Soto and Hayek to convert 'dead capital' into political economic freedom (Schmidt, 2018: 13). Through a lengthy, politically contingent process, the state declared the reserved lands-turned-municipalities to be 'natural persons', a legal status that facilitated 
contracts and corporate behaviours (2018: 12). Such measures are argued to structurally reinforce Indigenous dispossession as they undercut economic alternatives and deepen capitalist incursion into Indigenous places in settler colonial states. In New Zealand, Māori bids for public contracts entail Indigenous companies in 'race to the bottom' markets in resolutely neoliberal relations (McCormack, 2012). Elsewhere, the economic paradoxes of segregated spaces and colonial modern interpretations of indigenous peoples' economic practices come into focus. In the United States' southwest, an Indian reservation bought an urban tourist attraction in order to diversify income sources, but found itself tightly constrained by consumers' setter frontier fantasies (Barraclough, 2018). Aymara women's rapidly rising incomes from the informal sector in El Alto prompted house purchases and urban mobility into white wealthy neighbourhoods, yet did little to overcome racist suspicions about the source of women's wealth (Maclean, 2018). In these examples and others, ethnographic detail reveals the contingent subtle ways in which capitalist dynamics are hybridized with Indigenous ethics, practices and governance (Rivera Cusicanqui, 2014).

The choice of interpretive frame to examine Indigenous peoples as capitalist actors determines the visibility and analytical significance of Indigenous agency regarding control over resources and capitalism (see Howard-Wagner et al., 2018a). Settler colonial-Indigenous theory offers a means to examine the context for Indigenous actors who seek financial selfsufficiency under state and legal structuring and constraining influences on the expressions of indigeneity. Yet the baseline wealth and investor confidence of Anglophone settler colonial countries makes a significant difference to the options available to Indigenous corporations and neotribal capitalists, especially in comparison with under-resourced states and investment riskiness in middle and low-income countries.

\section{Indigeneity and the legal basis of capitalist political economies}

Indigenous people exercise their agency in an explicitly capitalist framework, constituted and protected by a Western legal framework and create 'choices' about their negotiated gains which are seemingly not linked to universal positive rights. (Howlett et al, 2011: 317-18)

A key dimension of Indigenous economic experiences derives from the sociospatial dynamics of law. According to advocates, rights instruments provide a degree of protection for Indigenous populations and territories from the worst ravages of global capitalism (see reviews in $\mathrm{Li}, 2014$; Anthias, 2018). In practice, however, legal frameworks and treaties expose the ineluctable limits of colonial modern law as a mechanism for Indigenous empowerment. Historically, Indigenous territories and peoples have been inextricably interconnected with and bound to economic restructuring and capitalist pressures since colonialism, resulting in pervasive influences on the diverse economies that occasionally subsist in the interstices of mainstream economic activity. 
Today, law encapsulates Janus-faced effects which promise Indigenous development even while extending neoliberal conceptions of the subject, property and security into newly regulated areas (Engle, 2010; Brabazon, 2017). Legal instruments work to frame Indigenous society as a series of individuals able to cultivate business practices, thereby cutting across collective sociality and diverse forms of exchange, labour and valuation. A vibrant literature documents how specific (including nominally 'progressive') national legislation advanced to clarify Indigenous title in effect promotes privatization and establishes the necessary basis for external investments (see, among others, Pasternak, 2014; Kröger and Lalander, 2016; Anthias, 2018). Patterns at the national level are also evident in international provisions. The path-breaking ILO Convention 169 on Indigenous rights in 1989 was never intended as a mechanism to challenge political economic structures, not least because of the International Labour Organization's ambivalent position as a regulator of labour markets (Goodale 2015: 442-3). Paradoxically, rights instruments constrain options and undergird new forms of capitalist accumulation because of the "ineluctable, constant and veiled presence of transnational (primarily extractive) capital working not against, but with, policies of Indigenous rights" (Goodale, 2015: 441, added emphasis).

The United Nations Declaration of the Rights of Indigenous Peoples (UNDRIP) has also come under critical scrutiny in this regard. Among other principles, UNDRIP provides for Indigenous rights to self-determination, the right to develop priorities and strategies for the exercise of the right to development (Article 23), and rights to property and to financial and technical assistance from states (Article 39). Despite acknowledging the historic injustices produced by colonialism however, UNDRIP gives states no positive obligation under law to guarantee these rights to Indigenous peoples (Ciupa, 2017). Repeated violations of UNDRIP occur in states that, primarily incentivized by neoliberal goals, are unwilling or unable to enforce laws that might threaten foreign investment or provide only minimal protections compatible with capitalist interests (2017: 198-200). For instance, one UNDRIP principle is Indigenous peoples' right to free, prior and informed consent (not veto), an economic governance issue of increasing importance in the global extractive boom. In Canada and Bolivia, resource development policies only comply with UNDRIP to a limited extent and governments actively pursue natural resource extraction, moderated only partially by the Canadian courts and Bolivia's electoral and constitutional institutions (Tockman, 2018). UNDRIP's slippery and ambivalent framing can be summarised as "both liberal and anticolonial in that [its provisions] advance Indigenous peoples' freedom to pursue economic, social and cultural development" (Howard-Wagner et al., 2018b: 9). Its acknowledgement of colonialism's impact thereby "becomes about the elimination of impediments to the right to economic development" (2018b: 11). Such a formula has deep roots in western enlightenment and liberal thinking in which scarcity of resources and state-market relations inform false universals of a homo oeconomicus, and fails to incorporate Indigenous notions of community, collective property and the systematic violence of dispossession in its remit (Ciupa, 2017: 202). In summary, recent literature provides close analysis of themes historically raised by Indigenous peoples in their activism to re-work the law. 


\section{Conclusions}

The heterogeneous positioning of Indigenous peoples in economic relations arises from their structurally distinctive status regarding resource control and the geographically specific dynamics between capitalism and colonialism. Analysis of variegated neoliberal processes and governmentality is, to varying degrees, contextualised by reference to the colonial modern legacies in resource distribution, legal economic status, and permutations of recolonization. Indigenous peoples' economic relations are an integral yet subaltern component of wider economies, as the rare earths that power mobile phones frequently originate in the subsoil of Indigenous occupied lands and historic territories, and Indigenous labour historically and contemporaneously makes goods and services cheaper for the minority world. Debates around extractivism, neoliberalism and economic want are hence recent manifestations of five hundred year old disputes over monetary and normative values, resources and livelihoods. The paradox is that Indigenous populations have been constituted as Other to homo oeconomicus yet their embeddedness within the economic flows, labour processes and forms of accumulation that make the modern world belie any separation. Moreover the literature reviewed suggests that although early twenty-first century laws and economies constitute Indigenous subjects as 'equal but different', indigeneity comprises an intrinsically unsettled and precarious site from which to establish value, exchange and commodification.

Current literature delves into the grounded dynamics and contested meanings of economic activity - from solar plants to intellectual property rights -- to examine the highly contingent and diversified engagements within and across Indigenous groups. Richly descriptive and theoretically informed accounts on how Indigenous populations negotiate their collective or individual place in markets provide important insights into broader questions about neoliberalism, labour and embeddedness. ${ }^{7}$ The legal geographies that legitimate and empower non-Indigenous actors in economic dealings with indigenous subjects and places are also coming into focus. These dynamics are of course fundamentally political, mired in western understandings of sovereignty, personhood and racialized hierarchies of bodies.

Approached from postcolonial-decolonial perspectives however, the coverage of and questions about indigeneity's economies express few concerns about where and how research is being undertaken. Indigenous conceptions of value and economy are often absent so the messy, situated and place-specific interactions between Indigenous experience and western concept-objects (capitalism, neoliberalism) continue to be described in the vocabularies and the epistemic starting points of Western economic geography. While a number of key scholars in this field engage in the coproduction of knowledge, the language, concepts and frameworks used to apprehend Indigenous peoples' economic embeddedness remain

$7 \quad$ However the literature is selective, being dominated by studies in Anglophone settler colonial countries, raising questions about the comparability between areas and theoretical frameworks. Does the notion of neotribal capitalism have validity outside a wealthier country? In what ways do indigenous concepts of livelihood and value inform research? 
stubbornly in place. Decolonising the vocabularies and reference points used to describe specific relations and global patterns would serve to decentre dominant readings of economic relations, in two ways (see also Zurba et al., 2019). First, approaching indigeneity's economies within dominant economic frameworks renders the plurality, heterogeneity and dynamism of diversely classed and 'de-territorialized' individual and collective subjects as singular and in excess to normative economic relations. Decolonising by contrast would open up the "dark matter" (Goodale 2015) of diverse economic interests of heterogeneous Indigenous subjects. Second, decolonising accounts open up the potential to foreground alternative epistemologies and associated politics as illustrated in the epigraph from Silvia Rivera Cusicanqui. And it comes back to the politics. The reality of colonial-modern capitalism with place-specific configurations of variegated neoliberalisation provides limited scope for imagining -- let alone examining -- how the extraction of value from indigeneity and Indigenous resources could be reworked to overcome historic injustice.

\section{Acknowledgements}

This series of reports must end by acknowledging my position in writing about indigeneity and geography. Institutionally, my position reflects British involvement in dispossessing and dehumanizing Indigenous peoples historically and into the present, thereby contributing to my public university's endowment and claims to expertise. Yet within the academy, critical voices -- too few to be sure -- raise urgent questions to which white Europeans such as myself have to respond. Trying to unlearn privilege would not have begun without conversations and shared labour with Indigenous and non-Indigenous actors over many years in fields, buses and the ch'ixi spaces of multiepistemic dialogue outside (and in) universities across Abya Yala (=América), for which I am continually grateful and indebted. More immediately, earlier versions of this report received comments from Penelope Anthias, Piergiorgio di Giminiani, Siby Warrington-Brown, and Decolonial Research Lab reading group.

\section{References}

Allegretti A (2018) Respatializing culture, recasting gender in peri-urban sub-Saharan Africa: Maasai ethnicity and the 'cash economy' at the rural-urban interface. Journal of Rural Studies 60: 122-129.

Anthias P (2018) Limits to Decolonization: Indigeneity, territory, and hydrocarbon politics in the Bolivian Chaco. Ithaca: Cornell University Press.

Anthias P and Radcliffe SA (2015) The ethno-environmental fix and its limits: Indigenous land titling and the production of not-quite-neoliberal nature. Geoforum 64: 257-269.

Avila S (2018) Environmental justice and the expanding geography of wind power conflicts. Sustainability Science 13(3): 599-618.

Bargh M (2018) Māori political and economic recognition in a diverse economy, In D. Howard-Wagner, M Bargh and I Altamirano-Jimenez (eds) The Neoliberal State, Recognition and Indigenous Rights. Canberra: ANU Press, 293-307.

Bargh M, Douglas S and Te One A (2014) Fostering sustainable tribal economies in a time of climate change. New Zealand Geographer 70(2): 103-115.

Barraclough L (2018) Wrangling settler colonialism in the urban US West: Indigenous and Mexican American struggles for social justice. Annals AAG 108(2): 513-523. 
Bennett MB (2018) From state-initiated to indigenous-driven infrastructure: the Inuvialit and Canada's first highway to the Arctic Ocean. World Development 109: 134-148.

Bielefeld S (2018) Indigenous peoples, neoliberalism and the state: a retreat from rights to 'responsibilization' via the cashless welfare card, In D. Howard-Wagner, M Bargh and I Altamirano-Jimenez (eds) The Neoliberal State, Recognition and Indigenous Rights. Canberra: ANU Press, 147-165.

Bigenho M and Stobart H (2016) The devil in nationalism: Indigenous heritage and the challenges of decolonization. International Journal of Cultural Property 23: 141-166.

Borowiak C, Safri M, Healy S and Pavlovskaya M (2018) Navigating the fault lines: Race and class in Philadelphia's solidarity economy. Antipode DoI: 10.1111/anti.12368

Bozigar M, Gray CL and Bilsborrow RE (2016) Oil extraction and indigenous livelihoods in the Northern Ecuadorian Amazon. World Development 78: 125-135.

Brabazon H (ed) 2017 Neoliberal Legality. London: Routledge.

Bryan J (2017) Oil, indigeneity and dispossession. In S. Chari, S. Friedberg, V Gidwani, J Ribot and W Wolford (eds) Other Geographies: The influences of Michael Watts. Oxford: Wiley-Blackwell, 157-168.

Chan A S (2014) Networking Peripheries: Technological futures and the myth of digital universalism. Cambridge MA, MIT Press.

Chandra Y (2018) New narratives of development work? Making sense of social entrepreneurs' development narratives across time and economies. World Development 107: 306-326.

Ciupa K (2017) The promise of rights: International indigenous peoples' rights in the neoliberal era. In H Brabazon (ed) Neoliberal Legality. London: Routledge, 182-208.

De Leeuw S and Hunt S (2018) Unsettling decolonizing geographies. Geography Compass DoI: $10.1111 /$ gec3.12376

Di Giminiani P (2018) Entrepreneurs in the making: Indigenous entrepreneurship and the governance of hope in Chile. Latin American and Caribbean Ethnic Studies 13 (3): 259-281.

Engle K (2010) The Elusive Promise of Indigenous Development. Durham NC, Duke University Press.

Enns C, Bersaglio B and Kepe T (2015) Indigenous voices and the making of the post-2015 development agenda: The recurring tyranny of participation. Third World Quarterly 35(3): 358-375.

European Directorate-General for External Policies (2014) Indigenous Peoples, Extractive Industries and Human Rights. Policy Department EXPO/B/DROI/2013/23 September.

Gibson-Graham J-K (2006) A Postcapitalist Politics. Minneapolis, MN: University of Minnesota Press.

Gilberthorpe E and Hilson G (eds) (2016) Natural Resource Extraction and Indigenous Livelihoods. London: Routledge.

Golub A (2014) Leviathans at the Gold Mine: Creating Indigenous and Corporate Actors in Papua New Guinea. Durham, NC: Duke University Press.

Goodale M (2015) Dark matter: Toward a political economy of indigenous rights and aspirational politics. Critique of Anthropology 36(4) 439-457. 
Grydehøj A and Ou Z (2017) Deterritorialization of indigeneity: Indigenous territory, development policy and the Dan fishing community of Hainan (China). Political Geography 61: 77-87.

Hale C and Millaman Reinao R (2018) Privatization of the 'historic debt'? Mapuche territorial claims and the forest industry in southern Chile. Latin American and Caribbean Ethnic Studies 13(3): 305-325.

Horowitz LS (2018) 'It shocks me, the place of women': Intersectionality and mining companies' retrogradation of indigenous women in New Caledonia. Gender, Place and Culture 24(10): 1419-1440.

Howard-Wagner D, Bargh M and Altamirano-Jimenez I (eds) (2018a) The Neoliberal State, Recognition and Indigenous Rights. Canberra: ANU Press.

Howard-Wagner D, Bargh M and Altamirano-Jimenez I (2018b) From new paternalism to new imaginings of possibilities in Australia, Canada and Aotearoa/New Zealand: Indigenous rights and recognition and the state in the neoliberal age. In: D. HowardWagner, M Bargh and I Altamirano-Jimenez (eds) The Neoliberal State, Recognition and Indigenous Rights. Canberra: ANU Press, 1-39.

Howlett C, Seini M, McCallum D and Osborne N (2011) Neoliberalism, mineral development and indigenous people: A framework for analysis. Australian Geographer 42(3): 309-323.

Kedar A, Amara A and Yiftachel O (2018) Emptied Lands: A Legal Geography of Bedouin Rights in the Negev. Stanford, CA: Stanford University Press.

Korf B, Hagmann $\mathrm{T}$ and Emmenegger R (2015) Re-spacing African drylands: Territorialization, sedentarization and indigenous commodification in the Ethiopian pastoral frontier. Journal of Peasant Studies 42(5): 881-901.

Kröger M and Lalander R (2016) Ethno-territorial rights and the resource extraction boom in Latin America: Do constitutions matter? Third World Quarterly 37(4): 682-702.

LaDuke W (2009) Sustainable Tribal Economies: A Guide to Restoring Energy and Food Sovereignty in Native America. Minneapolis, MN: Honor the Earth.

Li, TM (2014) Land's End: Capitalist Relations on an Indigenous Frontier. Durham NC: Duke University Press.

MacArthur J and Matthewman S (2018) Populist resistance and alternative transitions: Indigenous ownership of energy infrastructure in Aotearoa New Zealand. Energy Research \& Social Science 43: 16-24.

Maclean K (2014) Evo's jumper: Identity and the used clothes trade in 'post-neoliberal' and 'pluri-cultural' Bolivia. Gender, Place and Culture 21(8): 963-978.

Maclean K (2018) Envisioning gender, indigeneity and urban change: The case of La Paz, Bolivia. Gender, Place and Culture 25(5): 711-725.

McCormack F (2012) Indigeneity as process: Māori claims and neoliberalism. Social Identities 18(4): 417-434.

Montsion JM (2015) Disrupting Canadian sovereignty? The 'First Nations and China' strategy revisited. Geoforum 58: 114-121.

O'Faircheallaigh C and Ali S (2008) Earth Matters: Indigenous Peoples, the Extractive Industries and Corporate Social Responsibility. Sheffield, Greenleaf. 
Pasternak S (2014) How capitalism will save colonialism: The privatization of reserve lands in Canada. Antipode 47(1): 179-196.

Pasternak S and Dafnos T (2017) How does the settler state secure the circuitry of capital? Society and Space 36(4): 739-757.

Radcliffe SA (2017) Geography and Indigeneity I: Indigeneity, coloniality and knowledge. Progress in Human Geography 41(2): 220-229.

Radcliffe SA (2018) Geography and Indigeneity II: Critical geographies of indigenous body politics. Progress in Human Geography 42(3): 436-445.

Radcliffe SA and Laurie N (2006) Culture and Development: Taking indigenous culture seriously in the Andes. Environment and Planning D: Society and Space 24(2): 231248.

Rata E (1999) The theory of neotribal capitalism. Review (Ferdinand Braudel Center) 22(3): 231-288.

Rata E (2000) A Political Economy of Neotribal Capitalism. Lanham MD, Lexington Books.

Rata E (2011) Encircling the commons: Neotribal capitalism in New Zealand since 2000. Anthropological Theory 11(3): 327-53.

Rights and Resources Initiative (RRI) (2016) Toward a global baseline of carbon storage in collective lands: An updated analysis of Indigenous peoples' and local communities' contributions to climate change mitigation. November. Washington DC: RRI.

Rivera Cusicanqui S (2014) The Potosí Principle: Another view of totality. E-misférica 11(1). Special issue on Decolonial Gesture. Available at: http://hemisphericinstitute.org/hemi/en/emisferica-111-decolonial-gesture/e111essay-the-potosi-principle-another-view-of-totality (accessed 5 September 2018).

Rose SW (2015) Two thematic manifestations of neotribal capitalism in the US. Anthropological Theory 15(2): 218-238.

Rye SA and Kurniawan NI (2017) Claiming indigenous rights through participatory mapping and the making of citizenship. Political Geography 61: 148-159.

Schmidt JJ (2018) Bureaucratic territory: First Nations, private property and 'turn-key' colonialism in Canada. Annals of the Association of American Geographers 108(4): 901-916.

Sheild Johansson M (2018) Taxing the Indigenous: A history of barriers to fiscal inclusion in the Bolivian highlands. History and Anthropology 29(1): 83-100.

Somerville M (2018) Naturalising finance, financialising natives: Indigeneity, race, and 'responsible' agricultural investment in Canada. Antipode 10.1111/anti.12395.

Stanley A (2016) Resilient settler colonialism: 'responsible resource development', 'flow through' financing, and the risk management of Indigenous sovereignty in Canada. Environment and Planning A 48(12): 2422-2442.

Stewart-Harawira M (2005) The New Imperial Order: Indigenous Responses to Globalization. London: Zed Books.

Tassi N (2016) The Native World-System: An Ethnography of Bolivian Aymara traders in the Global Economy. Oxford: Oxford University Press.

Tockman J (2018) Eliding consent in extractivist states: Bolivia, Canada, and the UN declaration on the rights of Indigenous peoples. International Journal of Human Rights 22(3): 325-349. 
Vilchis R (2018) Broadcasting in a native language: Speaking to every corner of Peru. New York Times, 21 June.

Wilson RS, Pearce T and Jones K (2018) Indigenous land management in peri-urban landscapes: An Australian example. Society and Natural Resources 31(3): 335-350.

Zurba M, Maclean K, Woodward E and Islam D (2019) Amplifying Indigenous community participation in place-based research through boundary work. Progress in Human Geography DoI 10.1177/0309132518807758. 